\title{
The Influence of Creativity on The Results of Islamic Religious Study Learning in Students Taught by Using The Learning Media Based on Information and Conventional Technology
}

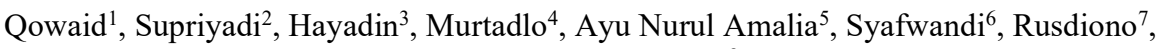 \\ Lisa'diyah Ma'rifataini ${ }^{8}$ \\ \{qowaidbmasyhuri@gmail.com ${ }^{1}$, supriyadiesbe@gmail.com², hayadin006@gmail.com ${ }^{3}$, \\ tadho25@gmail.com ${ }^{4}$, ayunurulamalia.ana@gmail.com ${ }^{5}$, syafwandi@menarasiswa.ac.id ${ }^{6}$, \\ rusdiono.pancasakti@gmail.com ${ }^{7}$, lisa.litbang@gmail.com $\left.{ }^{8}\right\}$ \\ IAI of Laa Roiba National ${ }^{1}$, STKIP of Panca Sakti2 ${ }^{2,7}$, The Center of Religius Education R\&D \\ Ministry of Religios Affair ${ }^{3,4,8}$, STIA of Menara Siswa ${ }^{6}$
}

\begin{abstract}
This study reveals the creativity of the Islamic religious learning outcomes of students taught by learning media based on information technology and conventional learning media. The interaction between creativity and learning media used on learning outcomes is also analyzed. Quasi-experimental research, the population of all first semester students of Economic Education Study Program. Using multi-stage random sampling techniques, valid and reliable instruments, and regression analysis. There is an interaction between creativity and information technology and conventional media on learning outcomes. Students taught with information technology media have no significant effect on learning outcomes with high and low levels of creativity. Students who are taught with conventional media, creativity has a significant effect on learning outcomes where the level of creativity is high, the coefficient of determination is $48.2 \%$, while the level of creativity is low, the coefficient of determination is $42.3 \%$.
\end{abstract}

Keywords: Creativity, Learning Media Based on Information Technology and Conventional, Islamic Learning Outcomes.

\section{Introduction}

Internal and external factors are variables that can affect student learning outcomes in Islamic religion courses. To optimize the learning outcomes of Islamic religion courses knowledge is needed about the influence of a factor and the interaction between factors. This study aims to determine the creativity factor on the learning outcomes of Islamic religious subjects in students taught by learning media based on information technology and conventional learning media. The interaction between creativity and learning media used in the learning outcomes of Islamic students was also analyzed.

Islamic religious education according to Bawani [1], religious education can be defined as an effort to actualize the attributes of perfection that have been bestowed by Allah SWT to humans, these efforts are carried out without any strings attached except to merely worship Allah SWT. 
Islamic religious education experts (2005) have tried to formulate an understanding of Islamic education, among the very varied boundaries are: Al-Syaibany argues that Islamic religious education is the process of changing the behavior of individual students on personal life, society, and the natural surroundings. The process is carried out using education and teaching as something of human and professional activity among the many human rights professions in society.

Muhammad Fadhil al-Jamaly defines Islamic education as an effort to develop, encourage and encourage students to live more dynamically based on high values and noble life. With this process, students are expected to form more perfect person, both related to the potential of reason, feelings, and actions.

Ahmad D. Marimba argued that Islamic religious education is guidance or leadership consciously by educators on the physical and spiritual development of students towards the formation of the main personality (insan kamil). Ahmad Tafsir defines Islamic education as guidance given by someone so that he develops optimally by Islamic teachings. The scope of Islamic teachings includes three fields, namely aqidah, shari'ah and morals which include: a) Aqidah meaning the language of bonding or connection. The plural is aqa'id. The meaning of aqidah according to the term is life belief or more specifically faith. In accordance with this meaning which is called aqidah is the field of faith in Islam by covering all things that must be believed by a Muslim / believer. Especially the area of faith included in the six pillars of faith, namely faith in Allah, in His angels, in His Books, in His Apostles, in the End, Times and the qada 'and Qadar. b) Shari'ah means the language of the road, while the meaning of the term is the rule of God which regulates human relations with the three parties of God, fellow human beings and nature altogether, God's rules governing human relations with God are called worship, and those that regulate human relations with fellow humans and the whole universe is called Muamalah. The five pillars of Islam are the creed, prayer, zakat, fasting, and pilgrimage, including worship, namely worship in a specific meaning whose material and procedures have been determined in a permanent and detailed manner in the Qur'an and the Sunnah of Rasulullah SAW. Furthermore, muamalah can be specified again, so that it consists of Munakahat (marriage), including the matter of inheritance (faraidh) and wills; Tijarah (commercial law) includes the matter of rents, debts, endowments; Hudud and jinayat are both Islamic criminal law. Hudud is the law for adultery, accusations of adultery, robbing, stealing and drinking. Whereas jinayat is a law for the crime of killing, injuring people, cutting members, and eliminating bodily benefits, in tinayat qishas applies namely "retaliatory law": Khilafat (Islamic government/politics); Jihad (war), including the matter of ghanimah (war booty) and captives).

Morals is derived from the Arabic plural of "khuluq" which means temperament or character. By the meaning of this language, then morality is part of Islamic teachings that govern human behavior. Ibnu Maskawaih defines morals by "the state of a person's soul that encourages him to do actions without thoughtful consideration". This character includes human morals to God, to the prophet/apostle, to oneself, to the family, to neighbors, to fellow Muslims, to non-Muslims. In Islam, besides ethics, the term ethics is also known. Ethics is a science that explains the meaning of good and bad, explains what humans should do to others, states the goals to be directed by humans in their actions and shows the way to do what must be done. So, ethics is a good deed arising from a person who does it intentionally and based on his awareness and in doing that he knows that it is included as good or bad deeds. Ethics must be accustomed from an early age, such as small children when eating and drinking accustomed to how eating ethics or drinking ethics, the habit of eating and drinking ethics from childhood will impact after adulthood. As is the case with dress ethics, girls are accustomed to wearing 
women's distinctive clothing such as headscarves while men wear kopya and so on. Islam is very concerned about the ethics of wearing as stated in Surah al-Ahsab above.

The observations made by researchers in the first semester students of the STKIP Panca Sakti Economic Education Study Program, for the value of Islamic religion courses which are general basic courses (MKDU), in the 2017-2018 academic year, found 59\% of students have a $\mathrm{C}$ value or a boundary value graduation of Islamic religion courses, This is a problem that must be resolved, especially by supporting lecturers of Islamic religion courses.

Understanding Learning Media Based on information technology IT (Information Technology) Media derived from Latin is a plural form of "Medium" which means "Intermediary" or "Introduction" that is an intermediary or introduction to the message source with the recipient of the message. Some experts define learning media.

Schramm [2] suggested that learning media is a messenger technology that can be utilized for learning purposes.

Brown [3] revealed that learning media used in learning activities can influence the effectiveness of learning. In the beginning, learning media only functioned as a teacher's aid for teaching which was used as a visual aid. Around the middle of the 21 st century, the business of visual utilization is complemented by the use of audio equipment, so an audiovisual aid is born. In line with the development of science and technology (science and technology), especially in the field of education, the use of learning aids or learning media is becoming more widespread and interactive, such as the presence of computers and the internet.

Creativity is one of the basic human needs, namely the need for self-realization (selfactualization) and is the highest need for humans [4].

Basically, every person is born in the world with creative potential. Creativity can be identified (identified) and fostered through appropriate education. Creativity is human tendencies to actualize themselves by the capabilities they have. Because of the diverse opinions of experts on the notion of creativity, it can be concluded that creativity is the ability of a person to produce a new product or a combination of things that already existed before, which is useful and can be understood [5].

Ayu Nurul Amalia's research [6] revealed that there is an influence of interaction between learning methods and creativity on the learning outcomes of students' videography.

This study presents the effect of creativity on learning outcomes of Islamic religious subjects in groups of students who are taught with information technology-based and conventional learning media which would not have been much studied.

\section{Research methods}

The research method used in this study is quasi-experimental. The population of this research is the first semester students of the economic education study program, STKIP Panca Sakti. The sampling technique used is multi-stage random sampling. The sample was grouped into four groups: two groups of students with high creativity, each of whom were taught with information technology-based learning media and conventional media, and two groups of students of low creativity who were each taught with learning media based on information technology and conventional media. Student creativity is categorized high if the creativity score is more than 76.70 and low if the creativity score is less than 62.90 based on analysis using Microcat ITEMAN software with the same number of samples per group, namely 30 
students. Data collection using the instruments of learning outcomes in Islamic religion courses in the form of multiple-choice tests and instruments of creativity in the form of attitude scales. The instrument of learning outcomes in Islamic religion courses is valid and has Alpha reliability of 0.792 . The creativity instrument is also valid and reliable with Alpha reliability of dimension I 0.674 , dimension II of 0.812 and dimension III of 0.753 . Data analysis techniques using simple linear regression analysis where creativity as the independent variable (X) and learning outcomes (Y) as the dependent variable. Regression analysis was performed on four groups, which then performed a comparison or comparison of each treatment group.

\section{Research result}

Description of student creativity score data is presented in the following table.

Table 1. Description of student creativity scores.

\begin{tabular}{|c|l|c|c|c|c|}
\hline Creativity & $\begin{array}{c}\text { Instructional } \\
\text { Media }\end{array}$ & Minimum & Maximum & Mean & $\begin{array}{c}\text { Standard } \\
\text { Deviation }\end{array}$ \\
\hline \multirow{2}{*}{ High } & IT Based & 88 & 96 & 84.89 & 4.23 \\
\cline { 2 - 6 } & Conventional & 78 & 85 & 74.15 & 3.24 \\
\hline \multirow{2}{*}{ Low } & IT Based & 61 & 73 & 62.24 & 2.31 \\
\cline { 2 - 6 } & Conventional & 43 & 62 & 41.31 & 4.22 \\
\hline
\end{tabular}

Description of the score data on the learning outcomes of Islamic religion students is presented in the following table.

Table 2. Description of learning outcomes of islamic subjects.

\begin{tabular}{|c|l|c|c|c|c|}
\hline \multirow{2}{*}{ Creativity } & $\begin{array}{c}\text { Instructional } \\
\text { Media }\end{array}$ & Minimum & Maximum & Mean & $\begin{array}{c}\text { Standard } \\
\text { Deviation }\end{array}$ \\
\hline \multirow{2}{*}{ High } & IT Based & 81 & 100 & 92.67 & 4.12 \\
\cline { 2 - 6 } & Conventional & 72 & 89 & 78.21 & 5.22 \\
\hline \multirow{2}{*}{ Low } & IT Based & 70 & 96 & 81.54 & 5.35 \\
\cline { 2 - 7 } & Conventional & 61 & 86 & 72.82 & 6.43 \\
\hline
\end{tabular}

The results of regression analysis on four groups of students using SPSS software can be summarized as follows. 
Table 3. Results of regression analysis.

\begin{tabular}{|c|l|c|c|c|}
\hline \multirow{2}{*}{ Creativity } & $\begin{array}{c}\text { Instructional } \\
\text { Media }\end{array}$ & $\begin{array}{c}\text { Regression Line } \\
\text { Equation }\end{array}$ & $\begin{array}{c}\text { P-value } \\
\text { Creativity } \\
\text { Coefficient }\end{array}$ & $\begin{array}{c}\text { Coefficient of } \\
\text { Determination }\end{array}$ \\
\hline \multirow{2}{*}{ High } & IT Based & $\hat{Y}=44.216+0.421 X$ & 0.142 & 0.037 \\
\cline { 2 - 5 } & Conventional & $\hat{Y}=121.135-1.062 X$ & 0.006 & 0.286 \\
\hline \multirow{2}{*}{ Low } & IT Based & $\hat{Y}=82.733-0.081 X$ & 0.931 & 0 \\
\cline { 2 - 6 } & Conventional & $\hat{Y}=112.052-0.937 X$ & 0.072 & 0.386 \\
\hline
\end{tabular}

From Table 3 above it can be concluded that creativity (X) does not significantly influence the learning outcomes of Islamic religious subjects (Y) on students taught with information technology-based learning media (IT) both with high and low creativity levels. Creativity affects the learning outcomes of Islamic religious subjects in students taught with conventional learning media, where the effect on students with low creativity is higher than students with high creativity.

\section{Discussion}

Creativity does not significantly influence the learning outcomes of Islamic religious subjects in students taught with information technology-based learning media (IT) both with high and low levels of creativity. This can be caused when lecturers use information technology-based learning media less involve students, the use of information technologybased media is only used as a show without inviting students to interact during lectures, so the lecture process goes unidirectionally which results in students being bored and less interested in the material delivered when This lecture, supported by Roger [7], states that feeling of pleasure will arise if students are in a class that includes their involvement in the classroom, have a personal relationship between teacher and student, use innovative learning methods, and have clear rules of behavior. this relates to the factor of developing creativity by allowing individuals to freely symbolically express their thoughts and feelings.

The results of this study differ from the research results of Ayu Nurul Amalia [6], revealing: (1) The learning outcomes of students who are taught using a discovery approach are higher than those taught using the demonstration method. (2) There is an interaction between the learning approach and creativity of the students' learning outcomes in videography. In Ayu's research that uses discovery learning methods, this learning method requires the role of students to be active in the learning process so that the learning process takes place not in the same direction but there is an interaction between students and educators which results in students' creativity in thinking increased. The results of this study support the opinion of Munandar[8] stating, in a creative person, if he has personal conditions and a supportive environment such as an environment that allows individuals to engage themselves creatively, then it can be predicted that their creative products will emerge. Creative learning can be seen from two sides, namely: (1) creative teaching and (2) teaching for creativity (Teaching for creativity). Creative teaching illustrates how lecturers can use imaginative approaches so that learning activities can be more interesting, arousing and effective. While 
teaching for creativity is related to the use of forms of learning aimed at developing students to have the ability to think and behave creatively.

Creativity has a significant effect on learning outcomes of Islamic religious subjects in students taught with conventional learning media.

The lecture process that uses conventional learning media in this study affects the learning outcomes of Islamic religious subjects, this can be caused by the lecturer delivery which is carried out step by step with the blackboard media so as to stimulate student curiosity, this student curiosity triggers student creativity, in the form of question and answer during lectures so that the lecture process can take place interactively or in two directions so that the understanding of lecture material can be better absorbed by students who impact on learning outcomes of Islamic religious subjects.

The results of this study support the opinion of Munandar [8], stating the factors that influence creativity can be in the form of thinking abilities and personality traits that interact with certain environments. The ability to think consists of intelligence (intelligence) and enrichment of thinking the material in the form of experience and skills. Personality factors consist of curiosity, self-esteem, and self-confidence, being independent, being risk-taking and being assertive. In a creative person, if you have personal conditions and a supportive environment such as an environment that allows individuals to engage themselves creatively, it can be predicted that their creative products will emerge.

Creativity is human tendencies to actualize themselves by the capabilities they have. Because of the diverse opinions of experts on the notion of creativity, it can be concluded that creativity is the ability of a person to produce a new product or a combination of things that already existed before, which is useful and can be understood. Each individual has a tendency or drives from within himself to be creative, realize the potential, express and activate all the capacities they have. This impulse is the primary motivation for creativity when individuals form new relationships with their environment to become fully themselves

\section{Conclusions}

From the results of the research and discussion in this study concluded that:

1. Creativity does not significantly influence the learning outcomes of Islamic religious subjects in students taught with information technology-based learning media both with high and low levels of creativity.

2. Creativity has a significant effect on learning outcomes of Islamic religious subjects in students taught with conventional learning media where the effect on students with low creativity is $48.2 \%$ and on students with high creativity is $42.3 \%$.

\section{References}

[1] Bawani, Imam, 1991, Cendikiawan Muslim dalam Perspektif Pendidikan Islam, Surabaya: Bina Ilmu Offset

[2] Schramm, W. (1977). Big media, little media: Tools and technologies for instruction. Beverly Hills, California: Sage Publications.

[3] Maslow, A.H.1976. The Farther Reaches of Human Nature. Middlesex: Penguin

[4] Utami Munandar 2009. Creativity Development of Gifted Children. Jakarta Rineka Cipta

[5] Amalia, Ayu Nurul. 2011. "The Effect of Learning Methods and Creativity Against Vocational Student Learning Outcomes in Vocational Schools". Thesis. Postgraduate Program, Prof. University Dr. Hamka 
[6] Rogers C.R 1982, Towards a theory of creativity, In P.E Vernon Creativity England Penguin Books.

[7] Munandar 2002, Creativity and giftedness, strategies to realize creative potential and talent, PT Gramedia Utama Jakarta 